\title{
PELAYANAN UPT PERPUSTAKAAN UNKHAIR DAN MINAT MAHASISWA DALAM MEMANFAATKAN UPT PERPUSTAKAAN UNIVERSITAS KAHIRUN TERNATE (Studi Survei Pada Mahasiswa Pengguna UPT Perpuistakaan Universitas Khairun Ternate Tahun 2009)
}

\author{
Oleh: Yuslinah Nurdiyani
}

\begin{abstract}
University library is a central service and information to support the Tri Dharma University. University library becomes one of the quality indicator of education in a university. Therefore, the services provided by the university library to the maximum in order to support all the needs of its academic civitas information especially students.

The study used survey method. This research studies 162 respondents from among the students of UPT Unkhair library user. Data techniques collection by questionnaire. Statistical methods using regression analysis. The services provided must be able to satisfy users in terms of collections, services personnel and infrastructure advice given, because the perceived unsatisfactory service will appeal to students to continue to use the library.

\section{PENDAHULUAN}

Di era globalisasi ini, informasi memegang peranan yang penting dalam segala aspek kehidupan manusia, baik itu informasi yang bersifat ilmiah ataupun non ilmiah. Setiap orang membutuhkan informasi sebagai bagian dari tuntutan kehidupan, penunjang kegiatan, dan pemenuhan kebutuhannya. Dalam perkembangannya, kebutuhan pengguna akan informasi juga akan berubah-ubah baik dari segi keragaman isi maupun akses terhadap informasi tersebut (Darsono, 2004). Semakin tinggi tingkat kebutuhan pengguna akan informasi, maka akan semakin beragam pula isi informasi yang dibutuhkannya.

Hal ini mungkin terjadi pada mahasiswa, karena mahasiswa pada dasarnya membutuhkan berbagai informasi yang berkaitan dengan aktivitas akademik atau informasi yang dapat membantu mereka untuk mengerjakan tugas tugas yang diberikan dosen, informasi terbaru tentang kondisi atau situasi terbaru di lingkungan sekitar mereka, maupun berbagai informasi lain yang berkaitan dengan minat pribadi mereka. Cara belajar mandiri di perguruan tinggi menuntut mahasiswa harus aktif dalam belajar dan tidak menunggu apa yang diberikan oleh dosen. Menurut Noerhayati (1987:72), dosen

hanya memberikan kuliah secara garis besarnya, sedangkan untuk detailnya mahasiswa diminta mengembangkan melalui buku-buku maupun bahan referensi lainnya dengan menggunakan berbagai sumber informasi yang tersedia. Sumber-sumber informasi tersebut antara lain dapat diperoleh di perpustakaan. Pkarena perpustakaan menyediakan berbagai bahan informasi seperti buku, jurnal, CD-ROM, internet, database online dan lain sebagainya yang dapat dimanfaatkan mahasiswa dalam memenuhi kebutuhan informasi mereka.

Perpustakaan Perguruan Tinggi merupakan sebuah pusat pelayanan dan informasi untuk menunjang Tri Dharma Perguruan Tinggi. Mengingat pentingnya perpustakaan perguruan tinggi dalam penyelenggaraan pendidikan, maka perpustakaan perguruan tinggi telah menjadi salah satu indikator mutu pendidikan di perguruan tinggi. Makin baik perpustakaannya maka makin baik pula mutu keluaran perguruan tinggi tersebut. Agar perpustakaan perguruan tinggi dapat mendukung perguruan tinggi tersebut maka perpustakaan harus didukung dengan koleksi yang bervariasi dan sesuai dengan kebutuhan pengguna, sarana prasarana yang memadai, sumberdaya manusia, dan pelayanan yang berkualitas.
\end{abstract}


Disamping itu perpustakaan juga harus dapat mengikuti perubahan perilaku pengguna seiring dengan perkembangan teknologi informasi di era globalisasi ini. Untuk itu setiap pengunjung terutama sivitas akademika berhak mengetahui dan mendapatkan pelayanan informasi apa saja yang dapat diperoleh di perpustakaan perguruan tinggi tersebut, sehingga nantinya pemustaka benar-benar dapat merasakan manfaat dari keberadaan perpustakaan perguruan tinggi yang ada dilingkungan studi mereka.

Universitas Khairun (Unikhair) merupakan satu-satunya Universitas Negeri di Maluku Utara. Perguruan tinggi ini memiliki perpustakaan yang cukup besar dan juga memiliki 7 perpustakaan fakultas. Koleksi yang ada di UPT perpustakaan Unkhair cukup lengkap hal ini terlihat dari adanya koleksi buku-buku yang sesuai dengan kurikulum, karena setiap melakukan pengadaan pihak perpustakaan selalu bekerjasama dengan masing - masing fakultas untuk menyesuaikan koleksinya dengan kebutuhan para sivitas akademikanya. Para petugas perpustakaan di UPT perpustakaan telah berusaha keras untuk memajukan perpustakaan dan menjalankan fungsinya dengan baik. Hal ini terlihat dari keramahan yang diberikan oleh pustakawan saat memberikan pelayanan serta program kerja yang telah disusun dan akan dilaksanakan. Sarana prasarana di UPT perpustakaan Unkhair dipandang dari segi estetika dan ergonomis juga cukup baik. Perpustakaan dilengkapi dengan ruang baca, ruang tamu, ruang referensi, ruang kerja dan juga tersedianya fasilitas penelusuran informasi yang dapat memudahkan mahasiswa dalam menemukan informasi yang diinginkan.

Namun belum adanya kebijakan dari masing - masing perpustakaan fakultas untuk memberlakukan sistem pelayanan terbuka bagi penggunanya membuat mahasiswa lebih banyak memanfaatkan UPT perpustakaan Unkhair. Hal ini dapat dilihat dari jumlah anggota UPT perpustakaan Unkhair yang semakin meningkat.
Dari tahun 2007 s/d 2008 jumlah anggota dari 3425 menjadi 4334 anggota yang berasal dari kalangan mahasiswa.

Oleh karena itu Penelitian ini dimaksudkan untuk mengetahui bagaimana pelayanan UPT Perpustakaan dan minat mahasiswa dalam memanfaatkan UPT perpustakaan Unkhair. Dengan mengetahui hal tersebut maka perpustakaan dapat melakukan berbagai upaya yang dapat memacu minat mahasiswa untuk terus memanfaatkan perpustakaannya.

Berdasarkan uraian yang telah dikemukakan pada latar belakang di atas, maka rumusan masalah yang akan dibahas dalam penelitian ini adalah "Bagaimana pengaruh pelayanan UPT Perpustakaan Unkhair terhadap minat mahasiswa dalam memanfaatkan UPT Perpustakaan Unkhair"?

\section{Kerangka Pemikiran}

Masyarakat sebagai kumpulan individu yang saling berinteraksi saling memberi dan saling menerima, memiliki harapan dan keinginan yang berbeda-beda merupakan subyek yang harus dilayani oleh perpustakaan secara merata dan optimal. Demikian halnya dengan masyarakat perguruan tinggi dan perpustakaannya, keduanya harus bersinergi dan bekerja bersama untuk mencapai tujuan yang diharapkan. Perguruan tinggi harus memberikan dukungan yang kuat kepada perpustakaan agar perpustakaan dapat memberikan layanan yang memuaskan bagi pemustaka.

Agar perpustakaan dapat menciptakan hubungan yang baik dengan pemustaka, maka ada beberapa syarat yang harus dipenuhi, yaitu:

a. Penyederhanaan administrasi perpustakaan.

b. Penyediaan koleksi yang baru dan memadai.

c. Pemberian layanan yang baik oleh staf yang ramah.

d. Pengembangan fasilitas layanan yang memadai sesuai dengan sistem dan tuntutan teknologi. 
e. Pengembangan gedung yang nyaman bagi pemakai.

Suatu perpustakaan dikatakan baik apabila mampu memberikan layanan sesuai dengan kebutuhan pemustaka. Keberhasilan layanan suatu perpustakaan tercermin dari kepuasan pemustaka. Pemustaka perguruan tinggi pada umumnya berasal dari kalangan mahasiswa. Mereka mengunjungi pepustakaan untuk mengakses informasi yang berkaitan dengan studi mereka, informasi umum, maupun informasi yang berkaitan dengan minat mereka. Oleh karena itu perpustakaan perguruan tinggi sebagai fasilitator dalam mendukung kebutuhan informasi mahasiswa memegang peranan penting. Jauh lebih baik bila perpustakaan menyedikan berbagai kebutuhan informasi yang diperlukan oleh mahasiswa. Kegiatan pelayanan sebuah Perpustakaan merupakan ujung tombak dari seluruh kegiatan yang dilaksanakan. Menurut Muhdhoffir (1986:64), dalam pelayanan itu sendiri terdiri dari empat unsur yaitu:

\section{a. Koleksi.}

Setiap perpustakaan tentunya mempunyai visi dan misi yang berbeda. Namun dapat dipastikan bahwa perpustakaan itu dikatakan berhasil bila banyak dimanfaatkan oleh komunitasnya. Salah satu aspek penting untuk membuat perpustakaan itu banyak dimanfaatkan adalah ketersediaan koleksi yang memenuhi kebutuhan penggunanya. Koleksi perpustakaan adalah semua pustaka yang dikumpulkan, diolah, dan disimpan untuk disebarluaskan kepada masyarakat pemustaka untuk memenuhi kebutuhan informasi mereka. (Perpusnas, 1999:1). Koleksi perpustakaan terdiri dari bahan cetak dan bahan non cetak. Bahan cetak dapat terdiri dari buku teks, bahan rujukan, laporan penelitian, makalah temu ilmiah, karya akademik, literatur kelabu, karya fiksi dan terbitan berkala. Sedangkan bahan non cetak dapat terdiri dari kaset, piringan hitam, $C D$ dan lain-lain.
Dengan demikian dapat dikatakan bahwa koleksi perpustakaan yang lengkap dan mutakhir merupakan daya tarik bagi pemustaka. Makin banyak dan lengkap koleksi yang dimiliki, maka makin tinggi intensitas sirkulasi buku yang pada akhirnya makin besar pula proses transfer informasi dan disinilah perpustakaan berfungsi sebagai media atau alat serta jembatan perantara antara sumber ilmu dan masyarakat.

\section{b. Petugas / staff}

Persaingan yang begitu ketat di berbagai layanan jasa perpustakaan membuat pustakawan yang terlibat didalamnya ingin memberikan yang terbaik bagi pemakainya terutama menyangkut hubungan dengan masalah pelayanan. H.A.S Moenir (2009:197) menyatakan bahwa agar pelayanan dapat memuaskan orang atau sekelompok orang, maka pelaku yang bertugas melayani harus memiliki empat kriteria pokok yaitu: 1) tingkah laku yang sopan, 2) cara menyampaikan, 3) waktu menyampaikan yang tepat, 4) keramahtamahan. Agar pelayanan dapat memuaskan pengguna, maka pelayanan harus berkualitas. Purwardarminta (1984) mengemukakan bahwa kualitas pelayanan itu adalah baik tidaknya sesuatu pelayanan.

Sutarno NS (2005:123) mengatakan bahwa ukuran keberhasilan dalam pembinaan layanan perpustakaan antara lain:

a) Pengunjung perpustakaan makin bertambah

b) Transaksi (Peminjaman - pengembalian) koleksi makin bertambah

c) Jangkauan makin luas.

d) Jenis layanan bervariasi

e) Terciptanya perasaan puas bagi pengguna perpustakaan

f) Timbulnya keinginan kembali ke perpustakaan oleh pengguna.

\section{c. Sarana Prasarana Perpustakaan}

Menurut Sutarno (2003:97) saran dan prasarana perpustakaan adalah semua benda dan 
barang serta fasilitas yang ada di perpustakaan dan digunakan untuk mendukung terselenggaranya kegiatan perpustakaan. Sarana prasarana yang lengkap, baik, mudah dan enak dipergunakan, menarik bentuk warna dan ukurannya secara langsung dan tidak langsung akan meningkatkan perhatian, citra dan kesan yang baik masyarakat terhadap perpustakaan. Menurut Rahman Hermawan dan Zulfikar Zen (2006:23) dalam era teknologi informasi, disamping sarana dan prasaraana yang bersifat manual diperlukan pula fasilitas yang mendukung kegiatan otomasi perpustakaan. Komputer dan fasilitas komunikasi telah menjadi bagian yang mutlak dan diperlukan perpustakaan. Teknologi informasi yang digunakan perpustakaan memerlukan dukungan sarana dan prasarana baik berupa perangkat lunak maupun perangkat keras.

\section{d) Pemustaka}

Pemustaka merupakan orang - orang atau pengunjung yang memanfaatkan perpustakaan untuk memperoleh informasi yang dibutuhkan. Baik tidaknya citra perpustakaan dapat dilihat dari barometer pengunjung yang memanfaatkan perpustakaan. Apabila dalam proses penerimaan layanan tersebut apa yang diterima oleh pengguna itu sesuai atau bahkan melebihi harapan dan keinginannya, maka hal tersebut dapat membuat pemustaka semakin berminat untuk mengunjungi perpustakaan tersebut serta berkemungkinan besar pemustaka tersebut merekomendasikan apa yang telah dialaminya itu kepada pemustaka lainnya. Sebaliknya apabila pemustaka merasa kecewa terhadap pelayanannya maka hal itu dapat mengurangi reputasi perpustakaan tersebut. Hal ini dikarenakan layanan yang diberikan tidak mencapai sasaran sehingga secara tidak langsung pemustaka akan meninggalkan perpustakaan tersebut dan tidak berminat untuk mengunjungi lagi perpustakaan tersebut.

Pemustaka di perguruan tinggi pada umumnya berasal dari kalangan mahasiswa.
Mereka akan berminat untuk memanfaatkan perpustakaan jika pelayanan yang diberikan oleh perpustakaan memberikan kepuasan. Menurut Sandjaja (2005) bahwa suatu aktivitas akan dilakukan atau tidak tergantung oleh minat seseorang terhadap aktivitas tersebut. Disini nampak bahwa minat merupakan motivator yang kuat untuk melakukan suatu aktivitas. (www.unika.ac.id).

Sutjipto (2001) menjelaskan bahwa minat adalah kesadaran seseorang terhadap suatu objek, orang, masalah, atau situasi yang mempunyai kaitan dengan dirinya. Artinya minat harus dipandang sebagai sesuatu yang sadar, karena minat merupakan aspek psikologis seseorang untuk menaruh perhatian yang tinggi terhadap kegiatan tertentu dan mendorong yang bersangkutan untuk melaksanakan kegiatan tersebut. (www.depdiknas.go.id/jurnal/45/ sutjipto/htm)

Dari uraian tersebut di atas dapat disimpulkan bahwa minat merupakan perpaduan antara keinginan dan kemauan yang dapat berkembang jika ada motivasi, serta menjadi daya penggerak seseorang untuk melakukan aktivitas dimana minat mempengaruhi perhatian, belajar, berpikir dan berprestasi.

Berkaitan dengan peran yang disandang sebagai mahasiswa, maka tidak terlepas dari motivasi mereka untuk berprestasi atau berhasil dalam studinya. Menurut Sondang P. Siagian (1995), motivasi dapat bersumber dari dalam diri seseorang (motivasi intrinsik) akan tetapi dapat pula bersumber dari luar diri seseorang (motivasi ekstrinsik). Seberapa kuat motivasi yang dimiliki individu akan banyak menentukan terhadap kualiatas prilaku yang ditampilkan baik dalam konteks belajar, bekerja maupun dalam kehidupan lainnya.

Di abad informasi ini, para mahasiswa semakin membutuhkan sumber informasi dan kemudahan akses informasi untuk menunjang proses pembelajarannya. Namun semua kebutuhan tersebut akan terasa berat apabila dipenuhi secara pribadi, dan salah satu 
alternatifnya adalah dengan memanfaatkan perpustakaan. Dalam memanfaatkan perpustakaan mahasiswa dipengaruhi oleh berbagai faktor yang mendorong, baik faktor internal maupun eksternal.

Faktor internal timbul dari dalam diri mahasiswa itu sendiri karena mereka termotivasi untuk mencapai prestasi sehingga mereka berminat memanfaatkan perpustakaan guna memenuhi kebutuhan informasi mereka. Sedangkan faktor eksternal adalah faktor yang bersumber dari luar diri mahasiswa yang dapat datang dari perpustakaan itu sendiri karena situasi dan kondisi perpustakaan meliputi koleksi, sarana prasarana, fasilitas layanan.

Adanya koleksi yang berkualitas, jumlahnya memadai, banyak ragamnya dan relevan dengan kebutuhan pemakai maka akan dapat memotivasi mahasiswa untuk memanfaatkan perpustakaan. Sarana prasarana yang lengkap dan memadai serta selalu mengikuti kebutuhan pemakai maka akan memberikan kemudahan dan kenyamanan kepada pemakai, adanya layanan perpustakaan yang prima (memikat, bersahabat, cepat, tepat dan akurat) maka akan menarik minat mahasiswa untuk memanfaatkan perpustakaan.

Gambar 1 Kerangka Pemikiran

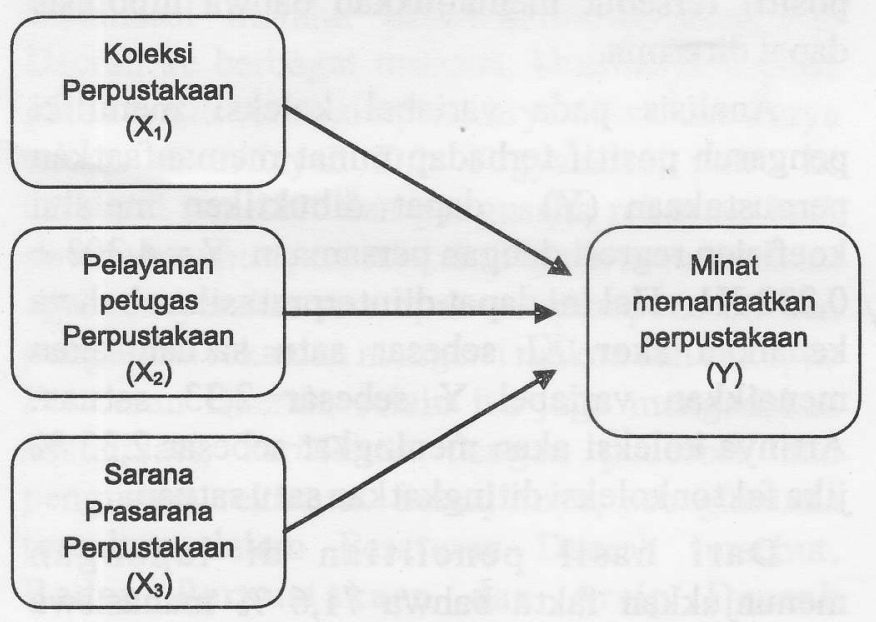

Definisi konsep dari masing - masing variabel dan indikator dalam penelitian ini adalah sebagai berikut:

1) Koleksi perpustakaan adalah semua informasi dalam bentuk karya tulis, karya cetak, dan / karya rekam dalam berbagai media yang mempunyai nilai pendidikan yang dihimpun, diolah, dan dilayankan oleh perpustakaan.

2) Sarana prasarana perpustakaan adalah semua benda dan barang serta fasilitas yang ada diperpustakaan dan digunakan untuk mendukung terselenggaranya kegiatan perpustakaan.

3) Pelayanan petugas perpustakaan adalah semua kegiatan yang dilakukan oleh petugas yang langsung berhubungan dengan pemustaka.

4) Minat memanfaat perpustakaan adalah adanya daya / keinginan yang timbul dalam diri seseorang untuk mendayagunakan sumber informasi, jasa informasi, dan sarana prasarana yang tersedia di perpustakaan.

\section{Metodologi Penelitian}

Penelitian ini menggunakan metode survei dengan alasan bahwa penelitian survei dapat dipakai untuk mengkaji seberapa jauh tujuan yang digariskan pada awal program tercapai atau mempunyai tanda - tanda tercapai. (Singarimbun, 1995:5). Dalam penelitian ini peneliti bermaksud menggambarkan secara terperinci dan mendalam tentang pelayanan UPT perpustakaan Unkhair dan minat mahasiswa dalam memanfaatkan UPT Perpustakaan Unkhair.

Dalam penelitian ini, peneliti mengambil 180 sampel dengan populasi pengunjung sekitar 200 orang dalam seminggu. Metode pengambilan sampel yang digunakan adalah menggunakan sampel acak sederhana (simple random) yaitu apabila semua anggota populasi diberikan kesempatan yang sama untuk dipilih sebagai sampel penelitian(Widodo, 2004:48). 
Teknik pengolahan data yang digunakan dalam penelitian ini antara lain;

- Kuesioner, merupakan pengumpulan data melalui daftar pertanyaan konkrit yang berhubungan dengan data yang diperlukan berdasarkan indikator - indikator dari variabel penelitian dalam bentuk angket dan disebarkan kepada responden.

- Wawancara (Interview), dilakukan untuk menggali secara lengkap dan luas serta berfokus pada informasi yang dikaji sebagai faktor pendukung dalam penelitian.

- Observasi memungkinkan peneliti mengamati dari dekat gejala yang diteliti, dalam hal ini peneliti semata-mata hanyalah sebagai pengamat, yaitu mengamati tentang pemanfaatan perpustakaan oleh mahasiswa dalam mencari informasi.

- Studi kepustakaan, dimaksudkan untuk memperoleh data sekunder berupa literatur- literatur landasan teoritis yang mendukung pada masalah yang diteliti serta menerjemahkan data - data yang telah diperoleh.

\section{5) Pembahasan}

Pelayanan merupakan tolok ukur keberhasilan sebuah perpustakaan karena penilaian pengguna akan muncul ketika kegiatan pelayanan tersebut dilangsungkan. Pelayanan adalah proses pemenuhan kebutuhan orang lain melalui aktivitas secara langsung. Payanan perpustakaan merupakan aktifitas perpustakaan dalam memberikan jasa layanan kepada pengguna perpustakaan, dengan beragam informasi dan berorientasi kepada pengguna. Pelayanan perpustakaan merupakan ujung tombak dari perpustakaan, Citra perpustakaan sangat bergantung pada bagaimana kualitas pelayanan yang diberikan oleh perpustakaan kepada penggunanya.
Minat mahasiswa memanfatkan perpustakaan adalah adanya keinginan untuk memenuhi kebutuhan informasi yang membuat mahasiswa terdorong untuk memanfaatkan perpustakaan guna memenuhi kebutuhan informasi. Dorongan tersebut dapat bersumber dari dalam diri mahasiswa (intrinsik) atau kesadaran diri untuk meningkatkan prestasi dan dorongan dari luar diri (ekstrinsik) yaitu adanya stimulus dari perpustakaan sendiri karena berbagai koleksi, sarana dan pelayanan yang memuaskan membuat mahasiswa tertarik dan berkeinginan untuk memanfaatkan perpustakaan.

Kuesioner yang dibagikan kepada responden berjumlah 180 , kuesioner yang memenuhi syarat untuk diolah sejumlah 162. Hasil analisis data menunjukkan sebagai berikut:

\section{1) Koleksi}

Pada tabel koefisien terlihat hasil probabilitas signifikan sebesar 0,004 lebih kecil dari angka tingkat kesalahan sebesar 0,05 maka dapat diketahui bahwa koefisien regresi $\mathrm{X} 1$ terhadap Y signifikan secara statistik dengan tingkat kepercayaan sebesar $95 \%$. Hasil analisis regresi ini menunjukkan bahwa antara variabel koleksi (X1) terhadap minat memanfaatkan perpustakaan (Y) menggambarkan adanya pengaruh positif. Dengan adanya pengaruh positif tersebut menunjukkan bahwa hipotesis dapat diterima.

Analisis pada variabel koleksi memiliki pengaruh positif terhadap minat memanfaatkan perpustakaan (Y) dapat dibuktikan melalui koefisien regresi dengan persamaan $Y=4,303+$ $0,233 \mathrm{X} 1$. Hal ini dapat diinterpretasikan bahwa kenaikan skor XI sebesar satu satuan akan menaikkan variabel $Y$ sebesar 2,33 satuan. Artinya koleksi akan meningkat sebesar 2,33\% jika faktor koleksi ditingkatkan satu satuan.

Dari hasil penelitian di lapangan menunjukkan fakta bahwa $71,6 \%$ mahasiswa mengatakan koleksi sudah sesuai dengan kebutuhan mereka. Hal ini dapat terjadi karena 
setiap melakukan pengadaan koleksi perpustakaan selalu bekerjasama dengan pihak fakultas maupun dosen - dosen untuk mengadakan pengembangan dan peningkatan koleksi guna menunjang kebutuhan pemakai terutama mahasiswa.

Oleh sebab itu perpustakaan perlu memiliki koleksi bahan pustaka yang relatif lengkap sesuai dengan visi, misi, perencanaan strategi, kebijakan, dan tujuannya. Koleksi bahan pustaka yang baik adalah dapat memenuhi selera, keinginan dan kebutuhan pemustaka. Kekuatan koleksi bahan pustaka itu merupakan daya tarik bagi pemustaka, sehingga makin banyak dan lengkap koleksi bahan pustaka yang dibaca dan dipinjam, akan semakin ramai perpustakaan dikunjungi mahasiswa dan makin tinggi intensitas sirkulasi buku. Akhirnya makin besar pula proses transfer informasi dan di sini perpustakaan berfungsi sebagai media atau alat serta jembatan perantara antara sumber informasi dengan pemustaka.

\section{2) Pelayanan petugas}

Petugas perpustakaan yang profesional diperlukan dalam upaya memberikan layanan yang memuaskan pemustaka. Selain perhatian terhadap pemustaka perlu pula dipikirkan bagaimana menciptakan hubungan baik dan berkelanjutan. Dengan demikian pustakawan akan memperoleh minimal dua keuntungan yaitu perpustakaan menjadi terkenal dan citra sebagai pustakawan profesional lebih terangkat.

Untuk mengetahui ada tidaknya pengaruh faktor pelayanan petugas (X2) terhadap minat memanfaatkan perpustakaan (Y), pada tabel koefisien kolom signifikan dimana probabilitas sebesar 0,009 lebih kecil daripada 0,05 maka dapat diketahui bahwa koefisien regresi $\mathrm{X} 2$ terhadap Y signifikan pada taraf kepercayaan 95 $\%$. Dengan demikian hipotesis kedua penelitian ini yang menyatakan adanya pengaruh antara pelayanan petugas (X2) terhadap minat memanfaatkan perpustakaan (Y) dapat diterima.

Analisis pada variabel pelayanan petugas (X2) memiliki pengaruh posistif terhadap minat memanfaatkan perpustakaan (Y) dapat dibuktikan melalui koefisien regresi dengan persamaan $Y=4,303+0,138 \times 2$. Hal ini dapat diinterpretasi bahwa kenaikan skor $\mathrm{X} 2$ sebesar satu satuan akan menaikkan variabel $Y$ sebesar $1,38 \%$ satuan. Artinya pelayanan petugas akan meningkat sebesar $1,38 \%$ jika faktor pelayanan petugas ditingkatkan satu satuan.

Pelayanan petugas perpustakaan juga memberikan kontribusi terhadap tingginya minat mahasiswa mengunjungi perpustakaan. Berdasarkan data yang diperoleh bahwa mahasiswa sering mengunjungi UPT Perpustakaan Unkhair antara 3-4 kali dalam sebulan. 56,2 \% mahasiswa menyatakan setuju bahwa mereka puas dengan pelayanan yang diberikan petugas. Dalam melayani pemustaka petugas perpustakaan selalu berusaha sebisa mungkin untuk memberikan informasi yang dibutuhkan pemustaka.

Dari uraian diatas dapat disimpulkan bahwa pelayanan petugas perpustakaan merupakan salah satu faktor penting yang dapat berpengaruh terhadap minat mahasiswa dalam memanfaatkan perpustakaan, Semakin baik pelayanan yang diberikan oleh UPT Perpustakaan Unkhair maka semakin menarik minat mahasiswa untuk memanfaatkan perpustakaan.

\section{3) Sarana Prasarana}

Sarana prasarana perpustakaan adalah semua peralatan dan perlengkapan pokok dan penunjang agar perpustakaan dapat berjalan baik. Oleh karena itu ketersediaan benda - benda dan barang yang sesuai dengan kebutuhan, kondisi, konstruksi, kualitas, ukuran dan persyaratan persyaratan tertentu sangat penting. Itulah alasannya mengapa ketersediaan dan ketercukupan sarana dan prasarana akan merupakan salah satu kekuatan perpustakaan (Sutarno NS 2003: 110). 
Dari hasil olah data didapatkan bahwa signifikan sebesar 0,007 lebih kecil dari angka tingkat kesalahan sebesar 0,05 maka dapat diketahui bahwa koefisien regresi X3 terhadap Y signifikan secara statistik dengan tingkat kepercayaan sebesar $95 \%$. Hasil analisis regresi ini menunjukkan bahwa antara variabel sarana prasarana (X3) terhadap minat memanfaatkan perpustakaan (Y) menggambarkan adanya pengaruh positif. Dengan adanya pengaruh positif tersebut menunjukkan bahwa hipotesis dapat diterima.

Analisis pada variabel sarana prasarana memiliki pengaruh positif terhadap minat memanfaatkan perpustakaan (Y) dapat dibuktikan melalui koefisien regresi dengan persamaan $Y=4,303+0,367 X 3$. Hal ini dapat diinterpretasi bahwa kenaikan skor X3 sebesar satu satuan akan menaikkan variabel $Y$ sebesar 3,67 satuan. Artinya sarana prasarana akan meningkat sebesar 3,67 \% jika faktor sarana prasarana ditingkatkan satu satuan.

Dari uraian tersebut dapat disimpulkan bahwa sarana prasarana merupakan salah satu faktor utama dalam memarik minat mahasiswa untuk memanfaatkan perpustakaan. Semakin baik sarana prasarana yang disediakan oleh UPT Perpustakaan Unkhair maka semakin menarik minat mahasiswa dalam memanfaatkan perpustakaan. Oleh karena itu perpustakaan perlu menyediakan berbagai sarana prasarana yang sesuai dengan kebutuhan mahasiswa sesuai dengan perkembangan teknologi sekarang ini. $\mathrm{Hal}$ ini akan sangat membuat mahasiswa semakin berminat untuk memanfaatkan perpustakaan.

\section{KESIMPULAN}

Berdasarkan hasil penelitian yang dilakukan maka dapat disimpulkan bahwa:

a) Hasil penelitian menunjukkan 71,6 \% responden menyatakan bahwa koleksi yang ada di UPT Perpustakaan Unkhair sudah sesuai dengan kebutuhan mereka. Sedangkan dari hasil uji hipotesis menunjukkan bahwa probabilitas sebesar 0,004 lebih kecil dari angka tingkat kesalahan sebesar 0,05 maka dapat diketahui bahwa koefisien regresi X1 terhadap Y signifikan secara statistik dengan tingkat kepercayaan sebesar $95 \%$, yang berarti bahwa hipotesis yang menyatakan adanya pengaruh antara koleksi (X1) terhadap minat memanfaatkan perpustakaan (Y) teruji dan dapat diterima.

b) Hasil penelitian menunjukkan bahwa $56,2 \%$ responden menyatakan puas terhadap pelayanan yang diberikan oleh petugas di UPT Perpustakaan Unkhair. Hasil uji hipotesis menunjukkan bahwa probabilitas sebesar 0,009 lebih kecil dari angka tingkat kesalahan sebesar 0,05 maka dapat diketahui bahwa koefisien regresi $\mathrm{X} 2$ terhadap $\mathrm{Y}$ signifikan secara statistik dengan tingkat kepercayaan sebesar $95 \%$, yang berarti bahwa hipotesis yang menyatakan adanya pengaruh antara pelayanan petugas (X2) terhadap minat memanfaatkan perpustakaan (Y) teruji dan dapat diterima.

c) Hasil penelitian menunjukan $63,6 \%$ responden menyatakan bahwa secara keseluruhan sarana prasarana di UPT Perpustakaan Unkhair cukup terpenuhi. Hasil uji hipotesis menunjukkan bahwa probabilitas sebesar 0,007 lebih kecil dari angka tingkat kesalahan sebesar 0,05 maka dapat diketahui bahwa koefisien regresi X3 terhadap Y signifikan secara statistik dengan tingkat kepercayaan sebesar $95 \%$, yang berarti bahwa hipotesis yang menyatakan adanya pengaruh antara sarana prasarana (X3) terhadap minat memanfaatkan perpustakaan $(\mathrm{Y})$ teruji dan dapat diterima.

\section{SARAN}

Berdasarkan pada hasil penelitian, maka peneliti memberikan saran - saran sebagai berikut: 
a) Koleksi dapat mempengaruhi minat mahasiswa untuk memanfaatkan perpustakaan. Oleh karena itu diharapkan mahasiswa diberi kelonggaran dalam hal peminjaman koleksi, agar peminjaman koleksi bagi mahasiswa dapat lebih diperbanyak lagi.

b) Perlu adanya program pengembangan sumber daya manusia (SDM) bagi petugas pelayanan untuk dapat meningkatkan kualitas pelayanan secara optimal dan berkesinambungan.

c) Selalu mengikuti perkembangan teknologi dalam hal memenuhi kebutuhan sarana prasarana bagi mahasiswa.

d) Guna mendukung minat mahasiswa untuk terus memanfaatkan perpustakaan maka UPT Perpustakaan perlu melakukan terobosan - terobosan baru salah satunya melalui media promosi, yang dapat dilakukan dengan cara menyelenggarakan pameran, seminar, lokakarya, bedah buku, lombalomba dan lain sebagainya yang sifatnya kontinyu sesuai dengan kebutuhan pengguna.

\section{DAFTAR PUSTAKA}

Badan Pengembangan dan Pemberdayaan SDM Kesehatan BPPSDMK. Peran perpustakaan dalam Mendukung Mutu Pendidikan di Poltekes Palangkarya, diakses tanggal 21 Maret 2009 , tersedia pada http://www.bppsdmk.depkes.go.id.

Darsono, 2004, Prilaku Pencarian Informasi Mahasiswa Magister Manajemen UNDIP yang Menggunakan Sumber Informasi Elektronik di Perpustakaan Magister Manajemen UNDIP, diakses tanggal 27 Maret 2009 , t ersedia pada http://eprints.undip.ac.id/3287/2/RM_END HAR PU-A2D05024.pdf.

Moenir, H.A.S. 2000. Manajemen Pelayanan
Umum di Indonesia. PT. Bumi Aksara, Jakarta.

Mudhofir, 1986. Persepsi mahasiswa terhadap kualitas pelayanan Perpustakaan Fakultas Sospol UNS, diakses tanggal 28 Mei 2009, tersedia pada http://www.daryono. staff.uns.ac.id.

Noerhayati. 1987. Pengelolaan Perpustakaan Jilid 1. Bandung: Offset Alumni.

Pendit, Putu Laxman, 1992. Makna informasi: lanjutan dari sebuah perdebatan. Dalam Kepustakawanan Indonesia: potensi dan tantangan. Editor, Antonius Bangun et.al. Jakarta: Kesaint Blanc, 1992.

Sandjaja, pengertian minat, diakses tanggal 23 Maret 2009 , tersedia pada http://www.unika.ac.id.

Siagian, Sondang P, 1995, Teori Motivasi dan Aplikasinya, Jakarta: Rineka Cipta.

Singarimbun, Masri dan Sofian Effendi (Ed.), 1989, Metode Penelitian Survei, edisi revisi, Jakarta:LP3S

Sugiyono, 1999: Statistik non parametris untuk penelitian. Jakarta : Raja Grafindo Persada.

Sutjipto, pengertian minat, diakses tanggal 23 Maret 2009 , tersedia pada www.depdiknas.go.id/jurnal/45/sutjipto/htm

Sutarno NS. Perpustakaan dan Masyarakat. Jakarta: Yayasan Obor Indonesia, 2003.

dalam dalam mengembangkan masyarakat informasi, Jakarta: Pantai Rei, 2005

Undang - undang Perpustakaan Nomor 43 Tahun $2007 \mathrm{Bab}$ V tentang layanan perpustakaan.

Widodo, 2004, Cerdik menyusun proposal penelitian, skripsi dan disertasi dilengkapi contoh, Jakarta : Yayasan kelopak.

Young, 1983, Jenis - jenis jasa perpustakaan perguruan tinggi: Achmad - Pustakawan 
madya ITS Surabaya, diakses tanggal 5 Mei 2009, tersedia pada www.library.its.ac.id/ news/120/ARTICLE/2009-10-14.html.

Zen Zulfikar, Etika kepustakawanan: Suatu pendekatan terhadap profesi dan kode etik pustakawan indonesia. 